\title{
THE WORD FORMATION PROCESS OF SLANG WORDS IN RICH BRIAN'S SONG TITLED DAT STICK
}

\author{
Teo Mujibul Hidayat1', Mu'man ${ }^{2}$ \\ ${ }^{1}$ IKIP Siliwangi \\ ${ }^{2}$ IKIP Siliwangi \\ ${ }^{1}$ teomh46@student.ikipsiliwangi.ac.id, ${ }^{2}$ muman@ikipsiliwangi.ac.id
}

\begin{abstract}
The purposes of this research were to analyze the word formation process of slang words in Dat Stick song. Word formation is a change of words from old form to the new form. This research used descriptive method because the researcher described the word formation process of slang word in the song into the word or sentence in detail. This research used a documentation method to collect the data. The researcher used Yule (2010) theory to analyze the slang word. There are 10 types of word formation process which consist of coinage, borrowing, compounding, blending, clipping, and back-formation, conversion, acronym, derivation, and multiple process. Based on these 10 types, the researcher found 5 type of words formation process of 16 slang words. There were 9 from the clipping process, 1 from multiple process, 3 from acronym process, 1 from coinage process and 2 from blending process. Based on the results above, the most formed words were the clipping process.
\end{abstract}

Keywords: Word formation, Slang words, Song

\section{INTRODUCTION}

Language is a tool for communicate to each other. Parmawati (2018) states that language has central role on intellectual development, social, and emotional students to supported success student and learn all of lessons. In linguistics, study about a language, word is the smallest element that can be uttered in isolation with objective or practical meaning. Word is a part of language because it is usually used by human to communicate with others. Communication is an important thing for life. Through the communication, people can express their opinion and idea. As time goes by, word can be changed. This phenomenon is also known as word formation process. Word formation is a change of words from old form to the new form. According to Yule in Hafiza (2020), there are ten processes of word formation. Those processes are coinage, borrowing, compounding, blending, clipping, and backformation. In addition, there are other processes based on Yule, they are conversion, acronym, derivation, and multiple processes. The little example is word ASAP (as soon as possible) and BTW (by the way). It is formed by the process of acronym, in which it is actually derived from As Soon As Possible and By The Way. Those words are called slang.

Slang is a language consisting of words and phrases that usually used by people in informal situations. It's supported Yanchung and Yanhong states in (Kartina, 2019) "Slang is part of a language that is out from the standard usage of daily life language that my consists of new vocabularies and phrases with extended meanings attached to the original terms or words that belongs to a particular group". In this modern era, slang is not only often used in daily conversation by teenagers, but also in songs, novels, magazines. Slang already become an inspiration for musician to add or used slang word in the lyric of song. The little of example is the musician named Rich Brian. 
There are some research that have been done related to slang found in lyric of song, movies, novel and KasKus. Some research focused on song lyrics (Raodhatul\& Ardi 2019; Puspitorini 2019; Evadewi, 2018; Haspo\& Rosa, 2018), The result shows that the most formed word were compounding and borrowing. It can be concluded that compounding and borrowing process the most found in a song's lyric. Another research focused on slangs used in movies (Hafiza\& Rosa 2020; Aramiko 2019). The purpose of this research is to identify types and the function of slang word. The result shows that the slang word formed by compounding, clipping, etc. There some research focused on slang used in novel (Setiawan\& Deliani\& Dewi 2019), and some research focused on slang word used in a KasKus (Pratama\& Imperiani 2019). The results about two research above show that the most formed words were borrowing process words.

Almost the research above is about analysing word formation process of slang word which used Yule theories. The researchers above used a qualitative method and documentation method for collecting the data. There are many researchers discussed about word formation process of slang word. This is also one of the reasons why the researcher wants to analysis word formation of slang word in a lyric of song.

In this research, the researcher would like to analyze and explain the word formation process of slang word in Dat Stick Song by Rich Brian. The first, what are the slang word that available in Rich Brian song titled dat stick and the second how are the word formation process of those slang words in Rrich brian song titled dat stick. To answer both of problems, the researcher used Yule (2010) theories to analysis the word formation of slang word that have been found.

\section{METHOD}

The method used in this research is descriptive qualitative method. This method used to describe or analyze the results of the study but not used for make broader conclusions (Sugiyono, 2005 cited in Apsari, 2017). In this research, the researcher analyzed the data and makes a description about the analysis of word formation process of slang words in Rich Brian's song titled Dat Stick. According to Kothari (in Hafiza 2020) defines the descriptive research is to describe the event or phenomena related to the object. The data or a result will be done by descriptive qualitative method. According to Borg W.R \& Gall (in Setiawati 2018) descriptive studies focus on the discovery of data on the question "What is" that observations and descriptive data.

The data of this research are word with contains slang words in Rich brian song' titled dat stick. This song was chosen because it is popular among teenagers. In this research, the researcher collected the data from lyric of dat stick song by Rich Brian. In gathering the data, the researcher used documentation method, the lyric was taken from browser. The steps of data analysis in this research were taken from the techniques proposed by Seiddel in Moleong (in Wati 2019). The steps of data analysis in this research are writing, categorizing and explaining the word formation process of slang words in Rich Brian song titled dat stick. The explanation of each step can be seen as follow.

The first, the researcher wrote the words containing slang words in the lyric of song on the paper in order to help the researcher easy to collect the data. The second, the researcher categorized the types of word formation of slang in order to make the researcher easy in analyzing the data, then the researcher classified the types of word processes. The type of word formation is compounding, multiple process, clipping, acronym, back-formation, coinage, 
blending, conversion, borrowing, derivation. The third, the researcher explains about how are process of formation of slang words in Rich Brian song titled dat stick.

\section{RESULTS AND DISCUSSION}

\section{Results}

In this part, the researcher would like to combine between result and discussion because this research is kind of descriptive qualitative research. The purpose of combining result and discussion is to make a reader easily understand about the result of this research. After analyzing the lyric Rich Brian song titled Dat Stick, the researcher found 16 data of slang words in the lyric of song. The researcher assumed those words as slang because those words not found in oxford dictionary while founded in online slang dictionary. It can be concluded, those words are categorized as slang because they are the creativity in creating new terms for the existing words, and they are only used by certain community. There are several examples of slang words that found in the lyric, they are 'em, mothafuckin', pop, 'bout. After gathering those slang words, the researcher analyzed those slang words based on the types of word formation. The researcher here used one theory, there is Yule (2010) theory. Based on theory above, there are ten types of word formation process, which of each type has its own definition. From ten types of Yule (2010) theories, the researcher found 5 types of words formation that forms the slang words in Rich Brian song titled dat stick, they are clipping, multiple process, acronym, blending and coinage. The following is the analysis of each types of slang word formation:

a) Clipping

Clipping is word formation that removing the front or the end of a word. It's also usually called by shortening. There are 9 clipping process found in forming slang words Rich Brian's song tittled dat stick. This is the analysis of several word that is formed through this process:

1) Eatin': The word eatin' is slang word and it is derived from word eating. This word called clipping because it was is shortening from originally word eating, but this word just cutting from spelling ' $g$ '. The process can be seen as follow: eating $\rightarrow$ eatin $+\left({ }^{\circ}\right)=$ eatin'.

2) Shakin': The word shakin' is slang word and it is derived from word shaking. This word called clipping because it was shortening from originally word shaking, but this word just cutting from spelling ' $g$ '. The process can be seen as follow: shaking $\rightarrow \operatorname{shakin}+\left({ }^{(}\right)$ = shakin'

3) Holdin': The word holdin' is slang word and it is derived from word holding. This word called clipping because it was is shortening from originally word holding, but this word just cutting from spelling ' $\mathrm{g}$ '. The process can be seen as follow: holding $\rightarrow$ holdin $+\left({ }^{\text {') }}\right.$ = holdin'.

4) Droppin': The word droppin' is slang word and it is derived from word dropping. This word called clipping because it was is shortening from originally word dropping, but this word just cutting from spelling ' $g$ '. The process can be seen as follow: dropping $\rightarrow$ droppin $+\left({ }^{\circ}\right)=$ droppin'.

5) Screamin': The word screamin' is slang word and it is derived from word screaming. This word called clipping because it was is shortening from originally word screaming, but this word just cutting from spelling ' $\mathrm{g}$ '. The process can be seen as follow: screming $\rightarrow$ screamin $+\left({ }^{\circ}\right)=$ spittin'.

6) Sprayin': The word sprayin' is slang word and it is derived from word spraying. This word called clipping because it was is shortening from originally word spraying, but this word just cutting from spelling ' $\mathrm{g}$ '. The process can be seen as follow: spraying $\rightarrow$ sprayin $+\left({ }^{\prime}\right)=$ sprayin'. 
7) 'Bout: The word 'bout is a slang word and it is derived from word about. This word called clipping because it was shortening from originally word about, but this word just

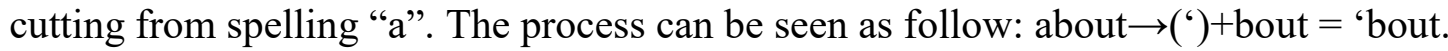

8) Yo: The word yo is slang word and it actually your which means belonging to the person or people that the speaker addressing. This word called clipping because it was shortening from originally word your, but this word just cutting from spelling 'ur'. The process can be seen as follow: your $\rightarrow$ yo $=$ yo.

9) 'Em: The word 'em is a shorter form of the word 'them'. 'Them' is a free morpheme that can be used in a sentence. Then 'em is classified as clipping word. The word 'em is omitted from the first part of the word from them. It is shortened by clipping some letters which is easier to say. The process can be seen as follow: them $\rightarrow \mathrm{em}\left({ }^{\prime}\right)=\mathrm{em}$ '.

After founding and analysis the word above. It can be seen that almost of word that founded has apostrophe at the beginning or the end of the word because there are letters that cut out.

\section{b) Blending}

Blending is a word formed from two word or a combination between two word to creating a new term. There are 2 blending process founded in forming slang words. The first is "ain't". The slang word "ain't" consists of two root words. They are 'am' and 'not', 'is' and 'not', or 'are' and 'not'. The first word 'am', 'is' and 'are' can be considered as a free morpheme and the second word 'not' that can stand on its own and have their meaning. The word formation that occurs here is blending. The word "ain't" is created by changing each part of the word. To combine them into a new word, they are omitted and changed the part of the word 'am', 'is', and 'are', and changed into 'ain'. Then, the second word 'not' are omitted and changed into ' $t$ '. So the words 'am', 'is', and 'are' are combined with the word 'not' to produce a single new term "ain't".

The second word is 'chigga'. This word is formed by combining two words, those are china and nigga. The beginning of the the word china "chi" is taken and the end of word of nigga "gga" is taken. By combining those, it will make a new term "chigga". This word used by African people to refer Asians people who are influenced by urban hip-hop culture.

\section{c) Acronym}

Acronym are abbreviation, such as ASAP (as soon as possible) and BTW (by the way). Acronym is usually formed from name or phrase and using initial letter of the word. Here, the researcher found three process of acronym. There are pop, imma and lil.

1) POP: The slang word POP is acronym process because word formed by combining the beginning letter of each word to create a shorter word which quicker word to refer Problem Oriented Policing. It's a simple process because, only taking the beginning word of Problem Oriented Policing to become POP.

2) Lil: The word Lil is derived from world little. Lil is the process of acronym because the word is shorter from the original word little. By taking letter ' 1 ' ' $\mathrm{i}$ ' and ' 1 ' from the word little and combining it to became lil.

3) Imma: The word Imma is contraction of I'm going to. This word is categorized by acronym because the word is abbreviation of I'm going to by combining letter ' $\mathrm{I}$ ' and double ' $\mathrm{m}$ ' and ' $\mathrm{a}$ ' at the end. This word firstly existed in the spoken language and making it into written form.

d) Coinage

Coinage is the invention of totally new words. Coinage is the processes of word formation by inventing from existing word to represent a new invention word. There are 1 coinage process 
founded in forming slang words in dat stick song, the term is youngins. The slang word youngins is a plural form of youngin and has the meaning young one or a child. This word is usually reduced form of young one.

\section{e) Multiple Process}

Multiple processes are the process of creating new words through more than one words formation process. Here, the researcher found 1 multiple process in forming slang words. The word is mothafuckin'. This word is categorized as multiple process because it is combining two types of word formation, they are clipping and compounding. The word Muthafuckin is derived from the word 'mother fucker'. Mother and fucking morphemes that can stand alone as a word. Mother-fucking is a word that having multiple-process in forming a new word. First is having a compounding process between 'mother' and 'fucking' become motha-fucking'. Then have a clipping process which cutting a letter at the end of the word then added a apostrophe at the end of the word 'fucking' to make the new words that have a different form of the word 'motherfuckin'.

\section{Discussion}

Language is a tool for communicate to each other. Language can change by over time. Therefore, the knowledge that learning about word is important in order to see a progress of change, including slang word. Slang is an informal language that usually used with a certain group of people. Teenagers are the most of using slang, usually in daily conversation or media social. However, sometimes slang is difficult to understand and don't know where it is come from. Therefore, the process of formation word can help to analyzing slang word. In this modern era, slang word not only found in daily conversation, but also lyric of song, novel, movies, magazines, comics. Since word slang has become popular in teenagers, the musician may think that slang is an inspiration to make a song interesting for teenagers by adding word slang in a lyric of song. In doing this research, the researcher used theories Yule (2010) about formation process in analyze and determine a slang word. According to Yule (2010), there are 10 types of word formation process which consist of coinage, borrowing, compounding, blending, clipping, and back-formation, conversion, acronym, derivation, and multiple process. Based on these 10 types, the results show that the most formed words were the clipping process.

Rich Brian, who sing this song, is musician known as a rapper from Indonesia. Rich brian always sung in English and put English language for his lyrics. The genre of song is kind of rap or hip-hop. Usually, kind of hip-hop song used a short word and singed with fast rhythm. It's quite different with another study about word formation that the analysis focused on song lyric. Those study are from Raodhatul\&Ardi 2019; Puspitorini 2019. Those research analysis song were Bruno mars and Young Lex. The genre of Bruno mars music is jazz and young lex is hiphop or rap. Young lex is also a rapper from indonesia, but he put Indonesian language for his lyrics. The results show borrowing in young lex song were the most and abbreviation process in Bruno mars were the most. It can be concluded that singer, language that used in the song and kind of song may affect to the result of the study. The similarity of this research only founded with the study that analysis Bruno mars song. There are many short words found. Clipping process and abbreviation have the similarity because this process is a process that changes the words to be shorter. 


\section{CONCLUSION}

After collecting several slang words in the lyrics of song and analyzing those slang words based on the types of word formation process, the researcher found 16 data of slang that is found in this song, which is there are 5 types of words formation that forms the slang words, there are clipping, multiple process, blending, acronym and coinage. In this song, most slang words that appear is from the clipping process.

\section{ACKNOWLEDGMENTS}

Alhamdulillahi rabil 'alamin, the writer expresses his highest gratitude to Allah subhanahu wa ta'ala for blessing, opportunity, love, health and mercy to complete this article. This article entitled "The Word Formation Process Of Slang Words In Rae Sremmurd Song Titled Swang" is submitted as the researcher curiosity to analyze the song using knowledge that the researcher acquired while learning in English Education Study Program, Faculty of Language Education at Institute of Teaching and Education (IKIP) Siliwangi.

Finally, I would like to thank everybody who was important to the successful realization of this article. This article is far from perfect, but it is expected that it will be useful not only for the writer, but also for the readers. For this reason, constructive thoughtful suggestion and critics are welcomed.

\section{REFERENCES}

Apsari, Y. (2017). The Use Of Picture Series In Teaching Writing Recount Text. Eltin Journal, Journal Of English Language Teaching In Indonesia, 5(2), 51.

Evadewi, R., \& Jufrizal, J. (2018). An Analysis Of English Slang Words Used In Eminem's Rap Music. E-Journal English Language And Literature, 7(1).

Hafiza, M., \& Rosa, R. N. (2020). An Analysis Of Word Formation Of English Slang Used In Straight Outta Compton Movie. E-Journal English Language And Literature, 9(1).

Pangestu, M. (2019). The Reasons Of The Main Character In Using Slang Words In Deadpool 2 Movie Directed By David Leitch. Wanastra: Jurnal Bahasa Dan Sastra, 11(1), 53-60.

Parmawati, A. (2018). Using Analytic Teams Technique To Improve Students'speaking Skill. Edulitics (Education, Literature, And Linguistics) Journal, 3(2), 21-25.

Pratama, I. B., \& Imperiani, E. D. A. (2020, April). Word Formation Processes Of Slang In Kaskus. In Twelfth Conference On Applied Linguistics (Conaplin 2019) (Pp. 97-101). Atlantis Press.

Pratiwi, V. Y., Jayanti, Y. D., \& Syathroh, I. L. (2019). An Analysis Of Lexical Cohesion Found In "Never Say Never" Song Lyrics. Project (Professional Journal Of English Education), 2(3), 377.

Puspitorini. F. (2019). An Analysis Of Slang Word In Song Lyrics Used By "Bruno Mars". The 3rd Indonesian International Conference On Linguistics, Language Teaching, Literature And Culture, 53(9), 1689-1699.

Raodhatul, A. P., \& Ardi, H. (2019). Word Formation Of Slang Word In Song Albums Created By Indonesian Rapper, Young Lex. E-Journal English Language And Literature, 8(3).

Setiawati, W., \& Maryani, M. (2018). An Analysis Of Figurative Language In Taylor Swift's Song Lyrics. Project (Professional Journal Of English Education), 1(3), 261-268.

Wati, S. K., Sufiyandi, S., \& Asridayani, A. (2019). Language Style Used In English Advertisements On Facebook: Stylistic Analysis. Krinok: Jurnal Linguistik Budaya, 4(1).

Yule, G. (2010). The Study Of Language. Cambridge University Press. 